\title{
Comprar, querer e desejar: problematizando as narrativas de crianças dos anos iniciais
}

\author{
Joice Araújo Esperança* \\ Paula Costa Ribeiro**
}

\section{Resumo}

Neste artigo, aborda-se os entendimentos e as experiências de infância como construçôes históricas, sociais e culturais, sujeitas às mudanças que caracterizam as sociedades. $\mathrm{Na}$ pesquisa apresentada, foram estabelecidas conexóes entre os Estudos da Infância, a Educaçáo Ambiental e as proposiçóes do sociólogo Zygmunt Bauman em seu exame sobre a centralidade assumida pelo consumo na organização da vida social. Nessa direção, volta-se o olhar para o advento do consumismo e as configuraçôes de infância na contemporaneidade, analisando as narrativas de um grupo de crianças sobre consumo. Nas experiências narradas, destaca-se a relaçáo entre consumo e preservaçáo ambiental, a penetrabilidade do ato da compra no cotidiano infantil e a atribuição de sentidos aos objetos e práticas de consumo para além de sua funcionalidade material. Palavras-chave: Infância. Consumismo. Educação Ambiental.

\footnotetext{
* Doutora em Educação Ambiental pela Universidade Federal do Rio Grande (FURG). Professora do Instituto de Educaçáo da FURG.

** Doutora em Ciências Biológicas pela Universidade Federal do Rio Grande do Sul (UFRGS). Professora do Instituto de Educação e da Pós-Graduação em Educação em Ciências e em Educação da Universidade Federal do Rio Grande (FURG).
} 


\section{Apontamentos introdutórios}

Neste artigo, abordamos os entendimentos e as experiências de infância como construções históricas, sociais e culturais, sujeitas às mudanças que caracterizam as sociedades. Sob esse viés, problematiza-se a imagem de infância universal e atemporal, amparada pelo pressuposto de que as identidades infantis são moldadas por traços biológicos invariáveis e estáveis. Assim, na esteira das reflexôes de estudiosos que examinam as infâncias numa perspectiva de análise não-essencialista, questionamos a existência de referentes naturais, fixos ou inalteráveis que determinam o ser criança (NARODOWSKI, 1999, 2001; BUJES, 2000, 2002; DORNELLES, 2005; BUCKINGHAM, 2007).

Dessa forma, compreendemos que os significados de infância são variáveis e estão em permanente mudança, pois são construídos e sustentados no contexto de sistemas compartilhados de significação, produzidos em condições históricas e culturais localizadas e específicas. Por estarem atreladas às práticas sociais, as noçóes de infância configuram formas de tratar e educar as crianças, afetando suas experiências concretas de vida e produzindo seus modos de ser.

Nessa direção, voltamos o nosso olhar para as configurações de infância na contemporaneidade, analisando-as em correlação ao advento do consumismo. Como estratégia, analisamos as narrativas de um grupo de crianças do Ensino Fundamental sobre consumo, produzidas em encontros realizados em uma escola da rede pública do município do Rio Grande, RS. Na pesquisa estabelecemos conexôes entre os Estudos da Infância, a Educação Ambiental e as proposições do sociólogo Zygmunt Bauman em seu exame sobre a centralidade assumida pelo consumo na organização da vida social.

Na próxima seção, tecemos relações entre infâncias, consumo e Educação Ambiental, demarcando alguns entendimentos acerca dessas temáticas que se articulam à pesquisa. Em seguida, apresentamos a contextualização deste estudo, situando a abordagem metodológica que subsidiou sua realização e problematizando a escolha de privilegiar as narrativas de crianças como material empírico. Na sequência, analisamos as falas das crianças sobre consumo, nas quais se destacam a relação entre consumo e preservação ambiental, a penetrabilidade do ato da compra no cotidiano infantil, o questionamento das oposiçóes entre necessidade e desejo e a atribuição de sentidos, para além de sua funcionalidade material, aos objetos e práticas de consumo. 


\section{Tecendo relações entre infâncias, consumo e Educação Ambiental}

Ao enfatizar a construção dos significados de infância e suas articulaçôes com as práticas de cuidado, assistência e educação que permitem intervir sobre a vida de meninos e meninas desde a mais tenra idade, forjando suas condutas e identidades, buscamos examinar as formas de conceber as crianças como efeito da conjunção de fatores sociais e discursivos inter-relacionados (BUCKINGHAM, 2007). Nessa perspectiva, compreendemos que os modos de ser e viver das crianças podem assumir muitas faces, variando conforme a época, o lugar, os grupos sociais, as relaçóes intergeracionais, os pertencimentos de gênero e etnia, dentre outros aspectos.

Seguindo essa linha de argumentação, é possível afirmar que, nas sociedades atuais, múltiplos discursos, instâncias e artefatos culturais incidem na construção das infâncias, tais como os saberes pedagógicos, as práticas institucionais, as crenças religiosas, as políticas públicas, os movimentos sociais, as expressóes artísticas, a mídia, a publicidade, a literatura, os brinquedos etc. No contexto dessa multiplicidade de atravessamentos que caracterizam a contemporaneidade, o consumo irrompe com intensidade e passa a operar como elemento definidor da vida em sociedade.

Examinar a singularidade atribuída ao consumo na atualidade e seus efeitos na vida das crianças implica considerar as alteraçóes históricas nas formas de consumir. Isso porque, enquanto meio de assegurar a satisfação de necessidades elementares dos seres humanos, o consumo pode ser visto como um aspecto inerente à manutenção da vida. Dessa maneira, pode-se dizer que todos nós somos e sempre fomos consumidores. Entretanto, conforme sinaliza Bauman (1999b, p. 88), o consumidor numa sociedade organizada em torno do consumo "é uma criatura acentuadamente diferente dos consumidores de quaisquer outras sociedades até aqui".

Para compreender o que torna o consumidor contemporâneo uma figura tão peculiar, é preciso atentar para o advento do consumismo. De acordo Bauman (2008), o consumismo chega quando o consumo assume um papel-chave nos processos de identificação e integração social, transformando a capacidade individual de querer, desejar e almejar numa força que coloca a sociedade atual em movimento e a mantém em curso como uma forma específica de convívio humano. "Acima de tudo, o consumismo tem o significado de 
transformar seres humanos em consumidores e rebaixar todos os outros aspectos a um plano inferior, secundário e derivado" (BAUMAN, 2011, p. 83).

A fim de abordar os diferentes significados que as formas de consumo adquirem ao longo do tempo, enquanto mediadoras das relaçóes entre os sujeitos, situo-as no contexto das análises de Bauman (2008) acerca dos dois arranjos societários que tomam forma no decurso da Modernidade ${ }^{1}$, designados, respectivamente, como "sociedade de produtores" e "sociedade de consumidores". Sob essa perspectiva, o referido autor destaca um aspecto que se torna crucial para o entendimento da distinção entre consumo e consumismo e, portanto, para a organização da vida em sociedade no cenário contemporâneo: a mudança de ênfase da "ética do trabalho" para a "estética do consumo" (BAUMAN, 2005).

De acordo com as análises de Bauman (1999b, 2001, 2005), a sociedade de produtores foi marcada por condiçōes como a expansão populacional e o incremento da produção, alavancada pelo processo de industrialização. Esse modelo societário, que viu nascer a indústria e vigorou na etapa "sólida" da Modernidade, concentrava-se na administração dos corpos, adaptando-os ao chão da fábrica e ao campo de batalha. A adequação às rotinas monótonas e às regras compartilhadas, bem como a aceitação resignada à ética do trabalho, eram, assim, as principais condutas a serem internalizadas e aprimoradas pelos membros dessa sociedade, os quais eram interpelados, acima de tudo, como produtores e soldados.

Ao discorrer sobre as condições que elevaram o trabalho ao posto de principal valor na sociedade de produtores, Bauman (2001) destaca que a ética do trabalho, isto é, a proclamação da virtude do trabalho pelo trabalho e a elevação de seu significado como a mais importante ferramenta de identificação social entre os indivíduos, pautava-se pelo preceito de adiamento da satisfação, de necessidades, desejos e experiências agradáveis. Valorizar o longo prazo e não o desfrute imediato de prazeres fazia sentido num mundo comprometido com a busca por segurança e estabilidade, em seu esforço para evocar disciplina e conformidade.

A passagem da sociedade de produtores para a de consumidores, ou o passo que vai da Modernidade Sólida à Modernidade Líquida, implica profundas alterações na condução das estratégias de vida e das formas de sociabilidade, pois é a capacidade de consumir que passa a coordená-las. Assim, opera-se o deslocamento da ética do trabalho para a estética do consumo, uma vez que a 
imbricação entre a vida e o mercado, as reconfigurações espaço-temporais, os avanços tecnológicos e a intensificaçáo das possibilidades de consumo depreciamse em longo prazo, instituindo o princípio da satisfação imediata, que postula: "Se a ética do trabalho pressiona por uma extensão indefinida do adiamento, a estética do consumo pressiona por sua aboliçáa”" (BAUMAN, 2001, p. 182). A estética do consumo articula-se, assim, ao modo de vida consumista, que valoriza não a obrigaçáo e o dever, mas as sensaçóes desconhecidas e sedutoras, a fruição de prazeres e o deleite momentâneo de desejos que se renovam continuamente. Nas palavras de Bauman (2005, p. 55-56, tradução nossa),

[...] é a estética e não a ética o elemento integrador na nova comunidade de consumidores, ele que mantém o curso dessa sociedade e, de tempos em tempos, resgata-a de sua crise. Se a ética marcava valor supremo ao trabalho bem realizado, a estética premia as mais intensas experiências. $\mathrm{O}$ cumprimento do dever tinha sua lógica interna que dependia do tempo e, por isso, estruturava-o, além de outorgar uma orientação, conferir sentido a noçôes como acumulação gradual ou demora nas satisfaçôes. Agora é diferente, já não existem razôes para postergar a busca de novas experiências.

As análises de Bauman (2007) sobre o advento do consumismo e a ênfase atribuída à estética do consumo nos processos de integração e reproduçáo social oferecem um importante ponto de partida para pensarmos sobre a constituiçáo das infâncias no tempo que vivemos, pois é num mundo no qual o consumo estabelece parâmetros para os modos de ser e viver, moldando escolhas e condutas individuais, que as crianças são educadas neste início de século. Em uma instigante reflexão sobre a vida líquida, isto é, a vida conduzida no ambiente da sociedade líquido-moderna de consumidores, o referido autor sinaliza as inextricáveis articulaçóes entre cultural infantil e consumo, enfatizando que, num ambiente social centrado em buscas consumistas e em empreendimentos individualistas, o fascínio pelas mercadorias e o impulso compulsivo e vicioso de comprar tornam-se as principais virtudes a serem promovidas e cultivadas nas crianças desde seu nascimento.

As "crianças do consumo", terminologia atribuída por Linn (2006) às geraçóes atuais, iniciam suas vidas como alvos privilegiados do marketing e da propaganda. Como sugerem as reflexóes dessa autora, que examina o fenômeno 
do consumismo infantil no contexto estadunidense, a relevância assumida pelas mídias eletrônicas no cotidiano das crianças de diferentes meios socioculturais implica o estabelecimento de vínculos estreitos entre formas de consumo simbólico e material, promovendo, assim, uma potente associação entre o entretenimento e o comércio. Por meio de acordos financeiros e licenciamentos, as produções midiáticas corporificam uma infinidade de produtos e serviços identificados pela imagem ou marca de personagens familiares às crianças. Ademais, o acesso às mídias potencializa a exposição das crianças a apelos comerciais, veiculados reiteradamente em canais de televisão, estaçôes de rádio e sites da internet, os quais disponibilizam desenhos animados, músicas, vídeos e jogos, anunciando produtos de seus patrocinadores.

As análises de Linn (2006) chamam atenção não apenas porque advertem sobre o crescimento descomunal do mercado de produtos infantis e do marketing segmentado, sustentado pela profusão de mídias eletrônicas, mas, sobretudo, porque explicitam que as açóes de marketing direcionadas às crianças promovem valores e visóes de mundo orientadas pela lógica consumista, afetando de forma indelével a formação dos sujeitos infantis. Essa constatação é reforçada pelo estudo de Schor (2009), que classifica as crianças contemporâneas como "nascidas para comprar".

Em seu estudo sobre a emergência das crianças como foco privilegiado da cultura do consumo, Schor (2009) destaca a penetrabilidade do mercado e do marketing nas atividades e instituiçóes vinculadas às crianças, condição que provoca profundas alteraçóes nas experiências de infância. Ao discorrer sobre o fenômeno que denomina como "comercialização da infância", a autora destaca que as gerações mais jovens emergiram, contemporaneamente, "como as geraçôes mais materialistas, mais orientadas por marca e mais envolvidas pelo consumo em nossa história” (SCHOR, 2009, p. 6). As pesquisas desenvolvidas por Linn (2006) e Schor (2009) evidenciam que o mundo infantil é cada vez mais construído e regulado pelo consumo. Essas constataçôes se coadunam com as análises sociológicas desenvolvidas por Bauman $(2001,2005,2011)$ sobre a estética do consumo e o advento do consumismo, fenômenos que elevam o consumo à condiçáo de força motriz da vida em sociedade.

Diante desse quadro, as articulações entre as temáticas infâncias e consumo assumem relevância no âmbito da educação em geral, e da Educação Ambiental ${ }^{2}$ em particular, por suscitarem o debate acerca dos modos de ser criança que se engendram num mundo globalizado, marcado, dentre outros 
aspectos, pela proeminência dos processos socioculturais de aquisição, uso e fruição de mercadorias materiais e simbólicas, isto é, das práticas de consumo (CANCLINI, 2005). Tal debate interessa à Educação Ambiental, na medida em que possibilita refletir acerca das condiçôes de existência e formas de sociabilidade que se edificam no cenário contemporâneo e sobre as complexas configuraçôes de ordem social, política, cultural, econômica e ecológica que o caracterizam (REIGOTA, 2002).

Entretanto, ao destacar a importância do consumo para os estudos da infância e da Educação Ambiental, não temos a pretensão de empreender análises de cunho moralista ou acusatório, as quais acabam por restringir a compreensão do fenômeno do consumo a motivaçóes e condutas associadas a gastos desnecessários e desmedidos ou a aquisiçôes supérfluas e de caráter meramente ostensivo. Também não temos a intençâo de enfocar as crianças como reféns ou consumidores passivos diante das forças irrefreáveis do mercado e da mídia, embora isso não signifique desconsiderar a relevância da crítica ao consumismo para a Educação Ambiental, enquanto reflexão acerca das interaçôes dos sujeitos com o mundo material e da urgência de sua adequação a níveis ecologicamente sustentáveis.

Sendo assim, a compreensão do consumo como atributo da sociedade (BAUMAN, 2008) e as abordagens culturais, que atentam para as funções simbólicas e para os sentidos de identificação construídos pelos grupos sociais em suas relaçóes com os objetos e práticas de consumo (MCCRACKEN, 2003; ROCHA, 2006; BARBOSA; CAMPBELL, 2006; DOUGLAS; ISHERWOOD, 2009), ancoram a perspectiva analítica assumida neste trabalho. Acreditamos que a atenção às narrativas das crianças sobre consumo pode criar possibilidades de problematizaçáo acerca de aspectos decisivos da cultura e da vida em sociedade, que incidem na construção das experiências de infância na atualidade.

\section{Contextualização do estudo}

A pesquisa contou com a participação de um grupo de crianças ${ }^{3}$, meninos e meninas da faixa etária de oito a doze anos, estudantes, dos $3^{\circ} \mathrm{e} 4^{\circ}$ anos do Ensino Fundamental de uma escola da rede pública do município do Rio Grande, RS. Importa salientar que a escolha em privilegiar a participação das crianças não se deu ao acaso, mas no contexto de um caminho investigativo 
pautado pela reflexão acerca das implicações da pesquisa acadêmica e científica na construção e ressignificação dos sentidos correntes de infância.

Desse modo, as opçóes metodológicas delinearam-se a partir do questionamento das perspectivas adultocêntrica e normativa, que assumem a primazia nos estudos da infância (BUJES, 2002; CASTRO, 2001). Tais perspectivas delimitam possibilidades de perceber as crianças segundo os critérios de uma racionalidade científica alicerçada na visão linear e evolutiva do tempo de vida, identificando "a criança" como um "não adulto", um ser incompleto ou em vias de tornar-se adulto. Assim, as diferenças que as crianças apresentam em relação aos adultos, suas formas de ser e apreender o mundo, passam a ser interpretadas como faltas a serem superadas e como fenômenos dotados de uma generalidade abstraída de especificidades contextuais.

Todavia, ao demarcar o afastamento das perspectivas hegemônicas que caracterizam os estudos da infância e que impedem o posicionamento das crianças por suas experiências e culturas, não pretendemos sustentar uma noção de infância autônoma e desvinculada dos demais grupos geracionais (DELGADO; MÜLLER, 2008). Nesse sentido, não compreendemos que as crianças sejam proprietárias das narrativas que enunciam, tampouco acreditamos que os significados compartilhados nos encontros da pesquisa sejam exclusivos de um grupo de sujeitos. Essa compreensão, de que os ditos das crianças não constituem evidências em si mesmas, mas se conectam ao intercâmbio de significados no contexto de circunstâncias históricas e sociais, articula-se à abordagem metodológica que subsidiou o desenvolvimento desta pesquisa: a "investigação narrativa".

De acordo com Connelly e Clandinin (1995), a investigação narrativa consiste no estudo da forma como os seres humanos experimentam o mundo, por meio da construção e reconstrução de histórias pessoais e coletivas. A investigação narrativa apoia-se no entendimento de que os vínculos narrativos que operam na constituição identitária dos sujeitos são produzidos no interior da cultura, território em que se elaboram, interpretam e medeiam histórias. Esse repertório simbólico compartilhado possibilita a construçáo de sentidos acerca do que somos e do que nos acontece, forjando nossas maneiras de compreender o mundo e de relacionarmo-nos com ele (LARROSA, 1998, 2008).

Nessa direção, Larrosa (2008) destaca que a narrativa, enquanto modalidade discursiva, não seria o lugar de irrupção da experiência de si, a revelaçấo de uma interioridade privada ou um meio neutro que expresse a 
articulação temporal do que se viveu. Conforme o autor, o que os sujeitos enunciam sobre si mesmos articula-se às operações de narração, isto é, aos processos de contar, ouvir e contrapor histórias que se constroem na interdependência entre narrativas, no diálogo entre textos. Isso porque "cada pessoa se encontra já imersa em estruturas narrativas que lhe pré-existem e em função das quais constrói e organiza de um modo particular sua experiência, impóe-lhe um significado" (LARROSA, 2008, p. 70).

Durante os encontros da pesquisa, realizados numa escola da rede pública do município do Rio Grande, RS ao longo do segundo semestre letivo de 2010, com periodicidade semanal, a principal estratégia empregada para a produção de narrativas foi a conversa com as crianças, conjugada com a construção de autorretratos, a leitura de livros infantis e de histórias em quadrinhos, a elaboração de produçóes escritas, a realização de um questionário individual e de registros fotográficos. Cada participante escolheu um nome fictício para figurar na pesquisa, procedimento que assegura o anonimato das crianças no processo de análise do material empírico. A conjugação dessas diversas estratégias propiciou o diálogo entre pesquisadoras e crianças, assim como entre elas próprias, possibilitando a composição de narrativas sobre as experiências infantis em correlação com os sentidos e as práticas acionadas pelo consumo na contemporaneidade.

No processo de análise náo buscamos algo a ser decifrado ou revelado sobre as crianças, pois entendemos que as narrativas que compóem o material empírico são produzidas pela participação dos sujeitos infantis em redes de comunicação que formam o gigantesco e agitado conjunto de histórias, que é a cultura (LARROSA, 2008). Nesse sentido, o movimento analítico empreendido consistiu-se em identificar recorrências, regularidades e relaçôes de sentido entre o material empírico, rastreando condiçôes históricas, códigos socioculturais, mecanismos e práticas que possibilitam a elaboração de certas narrativas sobre o ser criança e as práticas de consumo em nossa época.

\section{Problematizando as narrativas das crianças sobre consumo}

Os primeiros encontros com as crianças na escola foram conduzidos a partir de um vídeo ${ }^{4}$ que abordava o objetivo e os procedimentos a serem adotados no desenvolvimento da pesquisa. Após transmitir o vídeo, buscamos dialogar com as crianças, explicando-lhes que, durante as visitas à escola, 
realizaríamos algumas atividades e conversaríamos a respeito de diversas formas de consumo. A fim de identificar os significados atribuídos pelas crianças à temática da pesquisa, questionamo-las sobre o que entendiam por "consumo" e "consumir". Ao reportarmos a esses encontros iniciais, ressaltamos que os principais significados atribuídos pelas crianças ao consumo enfatizavam aspectos elementares à sobrevivência biológica, como a ingestão de líquidos e alimentos. Também em relação às compreensões de consumo expressas pelas crianças em nossas primeiras conversas, destacavam-se questóes vinculadas à preservação ambiental, como o dispêndio de água e energia elétrica e o tratamento de resíduos sólidos, com ênfase na reciclagem de lixo. É o que expressa a conversa transcrita abaixo:

Pesquisadora: Para vocês o que é consumo? O que significa consumir?

Cristiano Ronaldo (9 anos): Eu acho que é consumo de água, tem também consumo de energia elétrica...

Pesquisadora: Sim, mas e o que mais vocês consomem?

Demi Lovato (9 anos): A água, a água que nós consumimos.

Robinho (10 anos): É, tem que economizar...

Demi Lovato ( 9 anos): Tem que economizar a água na hora de tomar banho, escovar os dentes, essas coisas...

Nilmar (10 anos): É e tem que botar o lixo na reciclagem. Cristiano Ronaldo (9 anos): Tem que cuidar do planeta. Miley (10 anos): Eu acho que consumo é comida, comer, beber...

Ao analisar as condições de produção das narrativas das crianças constatamos seus vínculos com as formas de abordagem sobre meio ambiente e consumo que circulam nos currículos escolares, sobretudo no contexto das aulas de Ciências e das práticas de Educação Ambiental vigentes na escola que constituiu o cenário de realizaçáo desta pesquisa. Tal assertiva se apoia na observação de que, por diversas vezes, as crianças mencionavam atividades escolares, tais como um painel exposto numa das salas de aula, sob o título "Cuidados com o Planeta Terra", e expunham conteúdos dos livros didáticos de Ciências e de seus próprios cadernos, com o intuito de justificar e legitimar suas compreensóes sobre consumo. Portanto, analisar o teor das falas das crianças e a recorrência do que foi dito inicialmente sobre consumo leva a considerar que as narrativas são construídas e mediadas no interior de 
práticas sociais e institucionalizadas, coativas e normativas, que sancionam e regulam os repertórios linguísticos, constituindo formas específicas de narração (LARROSA, 2008).

Contudo, ainda que se identifiquem continuidades entre as falas das crianças e as propostas educativas desenvolvidas na escola por elas frequentada, é importante enfatizar que as abordagens preservacionistas sobre meio ambiente e a discussão do consumo restrita às necessidades vitais e açôes pontuais não são exclusivas da instituição educativa em questão. Isso porque os saberes e as experiências corporificados nos currículos escolares vinculam-se a outros repertórios semânticos constituídos na cultura e às formas circunstanciais de organização da sociedade e da educação (MOREIRA; SILVA, 2008), tais como os agenciamentos legais, os discursos científicos, as demandas relacionadas ao mundo do trabalho e as concernentes aos movimentos sociais, as interpelaçóes midiáticas, dentre outros saberes e práticas que atravessam o tecido social. Sendo assim, ao tratar de temas como meio ambiente e consumo a partir de um viés que prioriza as açóes individuais, orientadas pela construção de conhecimentos advindos das ciências naturais, os currículos escolares articulam-se ao sistema de representações das relações entre ambiente e sociedade em operação no contexto contemporâneo.

Ainda que considere a pertinência das práticas educativas que intencionam a mudança de comportamentos diante dos aspectos físicos do ambiente, entendemos que a problematização acerca das práticas de consumo realizadas no contexto das propostas de Educação Ambiental não devem se restringir a tal forma de abordagem, que incorre na simplificação do fenômeno do consumo a dimensões materiais e utilitárias. Essa abordagem tem sido alvo de críticas por parte de estudiosos que empreendem análises sobre consumo em suas interfaces com a Educação Ambiental (PORTILHO, 2004; SAMPAIO, 2005; WORTMANN; RIPOLL; POSSAMAI, 2012), tendo em vista que, a partir desta, são ignoradas as funções simbólicas que o consumo adquire nas relações sociais, associando-o à condutas irracionais e predatórias, consideradas nocivas ao ambiente. Além disso, como destaca Rocha (2009), o entendimento do consumo contemporâneo como algo inscrito num plano puramente biológico, natural e universal assenta-se numa visão determinista de algo que pertence a uma dimensão totalmente diversa, como se existisse uma continuidade entre consumir oxigênio ou alimento e escolher marcas de carros, estilos de roupas ou modelos de telefones celulares, por exemplo. 
Mas, se as narrativas construídas nos primeiros encontros da pesquisa associavam o consumo à satisfação de necessidades vitais e à preservação ambiental, no transcorrer das conversas com as crianças, alguns deslocamentos foram sendo engendrados, possibilitando a construçáo de outros relatos e histórias, que se articulam ao fenômeno do consumismo contemporâneo. Ao problematizar, com as crianças, a ideia de consumo de uma perspectiva sociocultural, que abarca múltiplas práticas de aquisição material e fruição simbólica, motivadas não apenas por necessidades, mas por vontades, desejos e por sentidos compartilhados na vida coletiva, as compreensões acerca do consumo ampliaram-se, o que pode ser identificado no diálogo a seguir:

Pesquisadora: Além de comida, o que mais vocês consomem? Selena Gomez (9 anos): O que a gente compra?

Pesquisadora: $\hat{E}$, o que vocês compram? O que vocês assistem na televisão, as músicas que vocês ouvem e mais gostam, os brinquedos que vocês têm, as coisas que vocês colecionam, como aquelas figurinhas que vocês me mostraram, as revistas que vocês leem. Porque quando nós conversamos sobre todas essas coisas nós estamos falando de consumo, de consumir, entenderam?

Ronaldinho gaúcho (8 anos): Ah, entendi, tu queres saber sobre as coisas, assim, que a gente compra, que a gente vê, as coisas que a gente tem, que quer ganhar...

Pesquisadora: Isso mesmo, eu quero conversar com vocês sobre tudo isso.

Ben 10 (8 anos): Eassim tu vais descobrir umas informaçôes sobre nós?

Pesquisadora: Vou, vou sim, para poder estudar sobre as crianças desta escola e o consumo.

Esse diálogo explicita que as redes de comunicação constituídas na trajetória da pesquisa criaram outras condiçóes para a problematização acerca das práticas de consumo, desestabilizando os registros narrativos estabelecidos nas abordagens escolares. Isso leva a considerar a impossibilidade de neutralidade no processo de pesquisa, pois as situaçóes de interlocução entre pesquisadora e crianças, assim como as estratégias empregadas para a produção do material empírico, envolveram a negociação e a modificação de sentidos. 
Sendo assim, no seguimento da pesquisa, as compreensóes das crianças sobre consumo ampliaram-se por meio da proposição de algumas estratégias, tais como a discussão conduzida a partir da leitura de livros infantis e de histórias em quadrinhos. A partir de então, a ideia de consumo associada às aquisiçóes materiais e, sobretudo, à ação de comprar adquiriu proeminência, tornando-se recorrentes nas conversas, momentos em que as crianças descreviam objetos lúdicos e aparatos tecnológicos, como celulares, câmaras fotográficas digitais e computadores portáteis, que almejavam adquirir em datas festivas, como o Dia das Crianças e o Natal. Contudo, embora as crianças vinculassem alguns pedidos e desejos ao Dia das Crianças e à troca de presentes característica das comemorações de final de ano, o que chama atenção em suas histórias é a trivialidade que o ato da compra adquire no cotidiano infantil. Ao afirmar isso, pretendemos ressaltar que o comprar é narrado pelas crianças como uma atividade que permeia as interaçóes familiares, os passeios, as opçóes de lazer e as vivências entre pares.

Nessa direção, destacamos uma conversa conduzida a partir da produção de autorretratos, em que um menino se descreveu, mencionando que seu passeio preferido era "ir nos camelos, para comprar DVD de filme e CD de jogo de videogame" (Goku, 8 anos). Conforme seu relato, a opção de frequentar o camelódromo da cidade suplantava, inclusive, o interesse por visitar a pracinha a convite de seus avós nos finais de semana. Os meninos que integravam o grupo em que essa conversa transcorreu também ressaltaram que realizavam compras no camelódromo ${ }^{5}$ com certa assiduidade, salientando que nesse espaço comercial "as coisas sâo tri baratas" (Justin Bieber, 8 anos) e que, por esse motivo, "sempre dá para comprar alguma coisa, porque lá tem coisas até de um real" (Robinho, 8 anos).

As falas desses meninos são representativas de muitas outras em que as crianças caracterizavam espaços de compra, tais como o camelódromo e os supermercados, como as opçóes de passeio mais realizadas na companhia de seus familiares aos finais de semana. Importa destacar que os supermercados citados pelas crianças consistem em grandes centros varejistas; alguns dispóem de restaurante, sorveteria e loja de eletroeletrônicos, permanecendo abertos aos domingos e feriados.

A mesma situação é observada em relação ao Centro de Comércio Informal, pois a maior parte das bancas de camelôs funciona durante todos os dias da semana. Esses espaços comerciais, além de possibilitarem às crianças 
o acesso a bens e serviços, mantêm-nas atualizadas acerca do lançamento de mercadorias, tais como brinquedos e jogos. É o que sinaliza o diálogo transcrito a seguir, em que Lilly (8 anos) identifica o supermercado próximo a sua residência como o espaço que propiciou o contato com um novo modelo de boneca, sobre a qual afirma querer com veemência:

Lilly (8 anos): Eu quero assim, uma boneca que eu gostei. Têm duas bonecas que eu gostei, uma que vem com mamadeira e outra que não. Só que a outra que não vem com mamadeira tem umas pintinhas no rosto e quando tu colocas ela no sol vem as pintinhas e se tu colocas na sombra ficam mais pintinhas.

Pesquisadora: Eu não conheço essa boneca. Como tu ficaste sabendo sobre ela?

Lilly (8 anos): Da boneca? No Guanabara.

Pesquisadora: Ah, foi no supermercado Guanabara?

Lilly (8 anos): É, a primeira coisa que eu vi. Eu queria tanto essa boneca, eu queria tanto, mas eu não sabia ainda, ai tá, eu comecei a querer, querer, querer, querer... Pedi para a minha mãe, ai a gente procurou, não achou e tem lá no Guanabara agora de novo. Vai ser terça que eu vou ganhar ela, eu vou ganhar!

O que se torna significativo para as análises desenvolvidas neste trabalho, que focalizam as imbricações entre infâncias e consumo, é a constatação de que alguns espaços comerciais se configuram nas narrativas das crianças como lugares de referência, conhecidos e frequentados rotineiramente por elas e que promovem a associação entre compra, lazer e prazer. Esses territórios se articulam às experiências do grupo de crianças em questáo, constituindo dinâmicas de sociabilidade orientadas pelo consumo e que parecem atender suas expectativas e interesses de modo bastante eficaz. Isso não significa que os espaços públicos convencionais de lazer e convívio infantil, tais como as praças, os clubes, os bairros etc. não sejam mais frequentados pelas crianças ou que tenham perdido a importância de outrora, já que isso varia conforme os contextos e os grupos sociais. Portanto, o aspecto notório nas narrativas que compóem o corpus de análise desta pesquisa é que muito do que as crianças realizam em sua vida diária, inclusive em momentos de distração, diz respeito à atividade de ir às compras, ao envolvimento com mercadorias e às suas relaçôes de consumo (SCHOR, 2009). 
As narrativas construídas na trajetória da pesquisa também colocam em evidência a profusão de espaços e tempos de consumo na contemporaneidade e a expansão do mercado de consumo popular, condiçóes que ampliam as possibilidades de acesso a bens e serviços a um maior contingente de sujeitos, esmaecendo as fronteiras de classe e envolvendo todas as categorias de idade nas tramas do consumismo. Nesse sentido, espaços comerciais como o camelódromo garantem às crianças que não dispóem de renda própria, mas que podem arcar com pequenas despesas, o acesso a réplicas ou imitaçōes de mercadorias, como DVDs de filmes, seriados e desenhos animados em voga na televisão e no cinema, CDs de jogos de videogame, brinquedos como a boneca Barbie, relógios e óculos focalizados em propagandas midiáticas. É o que explicitam as seguintes falas: "Nos camelôs não tem o produto original, que dura mais que esses 'paraguais', mas lá é bem mais barato, eu tenho uma coleção de óculos Ray-Ban" (Isabela, 10 anos); "Eu tenho a camisa do Grêmio oficial, mas nos camelôs têm outras que não têm os detalhes, assim, da oficial, que eu acho que também é mais forte. Mas a dos camelôs é mais barata, né, tem um monte de gente que tem" (Victor, 9 anos). De acordo com Costa (2006), a imensa rede de comércio informal infiltrada nos meandros do tecido urbano expressa o caráter inescapável da interpelação ao consumo, vigente em nossa época, que possibilita a distribuição de "mercadorias simulacro" 6 entre diferentes grupos sociais de crianças.

A penetrabilidade do ato da compra no cotidiano infantil, identificada na trajetória da pesquisa, não é um fato isolado, pois se articula com normas sociais e valores culturais instituídos em nossa época, pois o comprar consiste na principal atividade que mobiliza a economia e o modo de vida consumista. Conforme Bauman (2001), o desejo, entidade volátil e efêmera que conduz os consumidores à busca de satisfaçóes por meio do consumo, tem a si mesmo como objeto constante e, por isso, está fadado a permanecer insaciável, qualquer que seja a quantidade de mercadorias (materiais ou imateriais) que marquem seu passado. Nesse sentido, o autor compara o engajamento dos sujeitos interpelados pela estética consumista a uma corrida, cuja linha de chegada se move de forma mais veloz que o mais rápido dos corredores. Essa maratona, uma vez iniciada, nunca chega ao fim, porque no mundo dos consumidores as possibilidades são infinitas e o volume de objetos sedutores à disposiçấo jamais pode ser exaurido.

O arquétipo dessa corrida particular em cada membro de uma sociedade de consumo está correndo (tudo numa sociedade de consumo é uma questão de escolha, exceto 
a compulsão da escolha - a compulsão que evolui até se tornar um vício e assim não é mais percebida como compulsão) é a atividade de comprar. Se "comprar" significa esquadrinhar possibilidades, examinar, tocar, sentir, manusear os bens a mostra, comparando seus custos com o conteúdo da carteira [...] entáo vamos às compras tanto nas lojas quanto fora delas, vamos às compras na rua e em casa, no trabalho e no lazer, acordados e em sonhos. [...] O código em que nossa "política de vida" está escrito deriva da pragmática do comprar. (BAUMAN, 2001, p. 87).

Também em relação à proeminência que o comprar assume nas narrativas das crianças, destacamos as ocasióes em que conversamos a partir de um livro infantil ${ }^{7}$, momento em que foram abordados aspectos relativos às escolhas de consumo e às relaçóes familiares. Nesses encontros, diversas crianças ressaltaram que costumavam acompanhar os adultos da família até o supermercado ou ao centro comercial da cidade e que, em decorrência disso, realizavam compras de seu interesse. Dessa forma, é relevante salientar que nas narrativas das crianças a expressão "comprar qualquer coisa" é constantemente reiterada, demarcando o ato de comprar como mais significativo do que a mercadoria a ser adquirida, a qual pode integrar uma lista infindável de itens que compóem o mercado de produtos infantis, tais como alimentos, doces, figurinhas, livros, DVDs, brinquedos, roupas, material escolar etc. Isso pode ser exemplificado a partir da seguinte conversa:

Perla (9 anos): Os meus pais são mais parecidos com os da Flávia [refere-se à personagem do livro infantil utilizado na pesquisa], porque eu sempre ganho alguma coisa quando eu vou no centro, nas lojas, no super...

Pesquisadora: E o que tu costumas ganhar quando tu vais a esses lugares, o que tu gostas de comprar?

Perla (9 anos): Eu gosto de comprar um monte de coisa, kit de costura pra fazer roupa para as minhas bonecas, livrinhos, Barbie, Polly... Quando eu saio eu também gosto de comprar brinco, anel, pulseira, roupa. E eu gosto de comprar filme também, qualquer coisa...

Pesquisadora: Ah, tu gostas de comprar filmes?

Perla (9 anos): É, eu tenho toda a coleção dos filmes da 
Barbie, da Hello Kitty eu tenho dez, da Polly eu tenho três, das Princesas da Disney quatro e cinco de terror, imagina...! E, como eu já te falei, quando eu saio com o meu avô ele sempre me compra alguma coisa. Eu também gosto de comprar coisas de escrever, diário...

Pesquisadora: E tu costumas ir ao supermercado com o teu avô e com os teus pais?

Perla (9 anos): Vou, o meu irmão pequeno também. Ele bota tudo dentro do carrinho. E eu peço iogurte, bala, pirulito, chiclete... E também quando eu vou no centro eu gosto de comprar roupa da Renner e da Marisa.

Pesquisadora: E tem alguma coisa que tu já pediste e não ganhaste?

Perla (9anos): Já, às vezes o meu pai diz umas coisas, mas me dá, e às vezes eu não ganho porque eu peço tudo, né?!

"Comprar alguma coisa" e "ganhar qualquer coisa" são expressões que afirmam a celebraçáo do ato da compra em si mesmo, como uma conduta que se inscreve no cotidiano das vivências infantis, dispensando o planejamento em longo prazo ou a antecipaçáo de fins a serem perseguidos. O que buscam essas crianças em suas incursóes pelos espaços de consumo, o que anseiam quando se engajam de forma táo eloquente na "corrida dos consumidores" em sua vida diária, se não se manterem em contínuo movimento, experimentando sensações desconhecidas e inesperadas que o encontro com objetos novos é capaz de proporcionar-lhes? Bauman $(2008,2011)$ emprega os termos "colecionador de prazeres" e "coletor de sensaçôes" para denotar essa condição existencial do consumidor contemporâneo; alguém que almeja não a posse, a apropriação ou o acúmulo de bens, mas seu consumo instantâneo, o que implica o uso imediato e a rápida substituição das mercadorias, em razáo do volume e da intensidade de desejos sempre crescentes que conduzem a vida organizada e regulada pelo consumo. Na visão de Costa (2010), essas condutas configuram novas formas de consumo que poderiam ser mais bem descritas como "comprismo", o desejo de adquirir de tudo para, em seguida, descartar e substituir.

As narrativas produzidas na trajetória da pesquisa também remetem à análise sobre como operam e circulam os objetos de consumo nas relaçōes sociais que se estabelecem entre as crianças no interior da escola. Nesse sentido, um aspecto recorrente é a afeição demonstrada por novidades e inovaçôes, dentre as quais se destacam aparatos tecnológicos, como telefones celulares e computadores portáteis. 
Desse modo, durante os encontros da pesquisa, as crianças descreveram de forma vívida e detalhada essas mercadorias, embora nem sempre compreendessem a funcionalidade dos equipamentos eletrônicos que almejavam adquirir. Na ocasião em que Neymar (10 anos) mencionou que seria presenteado no Natal com um "telefone de mexer na tela", indaguei-o sobre a diferença entre esse modelo de celular e os outros, a fim de compreender a importância que esse item de consumo assumia para ele e outras crianças participantes da pesquisa. Foi entấo que o menino respondeu: "Eu acho que é porque é de usar a internet".

Além de Neymar (10 anos), na trajetória da pesquisa conversei com diversas crianças que desconheciam as especificidades utilitárias dos celulares recém-lançados ${ }^{8}$ e que possuíam telefones móveis, que atendiam suas necessidades de comunicação. Contudo, essas condições não colocavam em xeque o desejo de adquirir um modelo de celular mais recente e aperfeiçoado, o que pode ser constatado em outras falas: "Eu queria um telefone de tocar na tela, eu acho que vem uma canetinha também. Ele tem um monte de coisas, música, jogos, mas eu acho que ele também faz outras coisas, não sei..." (Cléo, 9 anos); "De Natal eu vou ganhar um celular de tocar com o dedo, igual ao do $S$. Eu tenho um celular, mas o meu é velho, parece de um milhão de anos" (Colorado 1, 8 anos). Essas falas evidenciam que os significados atribuídos pelas crianças aos objetos de consumo, tais como os celulares, não se restringem a sua funcionalidade material, mas se relacionam aos preceitos que orientam a economia consumista, em que a oferta excede a capacidade de demanda; e a regra é que, primeiramente, os bens apareçam, sejam inventados e planejados para que depois sejam encontradas suas aplicações (BAUMAN, 2008).

Se na sociedade de produtores os bens eram avaliados por seu volume, durabilidade e estabilidade, condiçốes que atendiam à busca por segurança em longo prazo, isso não se aplica ao ambiente da sociedade de consumidores, em que os imperativos da novidade e da obsolescência reduzem abruptamente o ciclo de vida das mercadorias (LIPOVETSKI, 2007), favorecendo as disposiçóes de querer e desejar e, por conseguinte, a ânsia por descartar e substituir. Quais bens de consumo, se não os celulares, melhor se adaptam a essas disposiçóes? Conforme destaca Bauman (2001), os objetos leves e portáteis, como os telefones celulares, estão entre os principais objetos culturais da era $\mathrm{da}$ instantaneidade. Eles representam as reconfiguraçôes espaço-temporais em curso, permitindo o contato a qualquer momento, em qualquer lugar. Ademais, sua contínua reinvenção demarca a luta contra o peso e o tamanho, perigos 
que compartilham o destino da durabilidade e que mais ameaçam a vida para consumo, experimentada pelos membros da sociedade líquido-moderna.

A partir das estratégias empregadas na trajetória da pesquisa para a produção de narrativas, foi possível identificar a alusão aos telefones celulares, bem como a outros equipamentos tecnológicos, como emblemas ou símbolos que possibilitavam às crianças compartilharem sentidos de pertencimento e distinção social. $\mathrm{Na}$ construção dos autorretratos, por exemplo, a maioria destas fez questão de se desenhar portando um smartphone, um notebook ou uma câmara fotográfica digital, a fim de demarcarem suas atividades favoritas e atribuir notoriedade à posse dessas mercadorias.

Nessa direção, destacamos que, mais do que possuir, foi possível constatar que, entre as crianças, tornava-se premente dar visibilidade ao que possuíam. Isso se concretizava por meio de diversas estratégias, tais como esconder o celular em compartimentos internos da mochila, diante da proibição de seu uso no espaço escolar, mas exibi-lo em sala de aula na ausência da professora, fotografar-se manuseando um notebook ou vestindo o look em voga no momento, isto é, as calças, óculos e tênis coloridos que compunham o figurino da Banda Restart ${ }^{9}$, a qual exercia enorme fascínio entre as meninas participantes da pesquisa. Esses itens de vestuário destoavam das cores do uniforme escolar, o que impedia seu uso na instituição pesquisada. Diante disso, as meninas afirmaram postar fotos usando as roupas coloridas no site da rede social $\operatorname{Orkut}^{10}$, com o intuito de compartilhar essas imagens com os colegas.

Além dessas estratégias, dentre outras que intentavam promover a visibilidade das possibilidades de consumo, em diversos momentos as crianças expressaram a importância de tornar explícito aos colegas seu potencial de consumo. Isso pode ser percebido nas falas que seguem: "Eu tenho um tênis colorido, igualzinho ao dela. Mas às vezes todo mundo acha que é mentira. As vezes todo mundo acha que é mentira as coisas que a gente fala que tem porque a gente não pode vir" (Mariana Rios, 10 anos); "O meu Ray-Ban [óculos de sol] a minha avó só deixa eu usar para sair, ninguém acredita que eu tenho, mas eu sei que eu tenho"(Miley Cyrus, 9 anos).

As falas das crianças evidenciam a relevância atribuída a alguns objetos nas relações sociais compartilhadas no contexto da escola. Esses objetos, transitórios e fugidios, operam como marcas de distinçáo, pois demonstram a face visível do consumo e da capacidade de escolha. A respeito disso, Bauman (1999b) esclarece que a sociedade de consumidores é uma sociedade estratificada e que, 
se todos nós estamos condenados à vida de opçóes, nem todos têm os meios de ser optantes. Assim, o exercício da escolha passa a ser o privilégio dos que estão posicionados no topo da hierarquia que categoriza os consumidores; é uma das condiçốes que faz com que alguns sejam percebidos como estando à frente ou acima dos outros, conforme expressam as seguintes falas: "Se a gente não tem dai os outros ficam por cima de ti, falando assim: eu tenho, tu não tens" (Vitória, 10 anos); "A minha mãe não deixa ninguém ficar por cima de mim, quando eu falo para ela que as gurias estão com as coisas novas eu peço e ela sempre me dä" (Juliana Paes, 9 anos).

Esse é um indicativo de que a admissão das crianças no contexto de alguns grupos que se formam nos espaços da escola passa a ser mediada pelo acesso a determinadas mercadorias, ou símbolos de pertencimento, que tornam as possibilidades de escolha publicamente reconhecíveis. Essas observações sinalizam que as disposiçóes de querer, desejar, comprar, descartar e substituir, demonstradas pelas crianças participantes da pesquisa, não estáo circunscritas à esfera individual, mas são mobilizadas por significaçôes compartilhadas em diversas instâncias de convívio social, tais como a instituição escolar e a família. Assim, não ter acesso a algumas mercadorias adquiridas por outras crianças, ou mantê-las por longo tempo, além do prazo em que seus substitutos novos e aperfeiçoados estiverem em oferta, passa a ser visto como sintoma de privação (BAUMAN, 2001), motivo de vergonha ou inadequação social. É o que sugere a fala de Elena (9 anos), ao justificar os motivos que a levaram a comprar as pulseiras coloridas usadas pela maioria das meninas da escola:

Elena (9 anos): Eu às vezes compro, né? Às vezes dou uma compradinha por causa das pessoas.

Pesquisadora: Como assim, por causa das pessoas?

Elena (9 anos): Assim, hoje eu vi as gurias com as pulseiras, eu já vi a L., quase todo mundo com as pulseiras, então, ai eu resolvi comprar uma.

Pesquisadora: Por que tu viste numa outra menina? Elena (9 anos): Não, porque eu fiquei envergonhada né, a única na escola sem pulseira, fiquei envergonhada.

Porque tem algumas gurias que não têm, mas tem um monte de gurias que têm.

A partir da fala de Elena ( 9 anos), percebe-se que algumas mercadorias que circulam nos espaços da escola e que se inscrevem nos corpos infantis, são 
capazes de outorgar sentidos às crianças que as possuem, bem como às que são privadas de sua posse. Nessa direção, Bauman (2008) assinala que, no contexto de uma sociedade que avalia seus membros por sua capacidade de consumir, os que não dispóem de recursos para reagir às seduçôes administradas pelo mercado, são marcados pelo estigma da exclusão, sendo percebidos como "consumidores falhos", indivíduos impossibilitados de participar do "jogo do consumo" e incapazes de viver segundo suas regras.

As possibilidades de estabelecer distinções e semelhanças entre indivíduos e grupos sociais pelo consumo evidenciam que as mercadorias desejadas e adquiridas pelas crianças, conforme já referimos, são dotadas de sentidos extrínsecos à sua funçâo utilitária. Esses sentidos, embora sejam apropriados e recriados pelas crianças em suas interações, não estão circunscritos ao contexto das vivências escolares, mas assumem relaçóes de interdependência e intertextualidade com outros repertórios de significação, dentre os quais os anúncios comerciais que circulam por meio da televisão ocupam lugar de destaque. Isso pode ser constatado em diversos diálogos em que as crianças citaram as propagandas televisivas como os principais meios de acesso às informaçôes sobre os produtos que intencionavam comprar.

Ao conversar com Hannah Montana (10 anos), a respeito da sandália da Barbie, com a qual seria presenteada por sua mãe, a menina explicou: "É uma que eu vi na propaganda, tem dois tipos, mas eu gostei só de um. Tem uma que vem com bolsa, que é a que eu quero, e tem outra que vem... ah, esqueci... acho que com um brinquedo". Quando a questionei sobre como ficou conhecendo o modelo de sandália vinculado à imagem de sua personagem favorita, a estudante respondeu de imediato: "Eu vi na TV, nunca vi em alguém". Assim como Hannah Montana (10 anos), outras crianças mencionaram as mensagens publicitárias nas conversas com a pesquisadora, como pode ser constatado nas falas que seguem: "Eu já vi uma botinha que vira, assim [refere-se ao calçado que estava usando], da Hello Kitty. E eu soube que outras da Hello Kitty iguaizinhas vêm com uma bolsa e vêm um brinquedo junto. Eu vi numa propaganda, eu sempre quis assim" (Gabriela Montez, 9 anos); "Eu vi numa propaganda no Cartoon [canal de televisão] o Max Steel e o Elemento Choque. Eu quero ganhar o Elemento Choque. Ele é inimigo do Max Steel' (Naruto, 9 anos).

Nas conversas conduzidas durante a pesquisa as crianças destacaram as propagandas televisivas como os principais meios de informação que conferem notoriedade a alguns itens de consumo infantil, como calçados, brinquedos, 
roupas e material escolar. Ademais, os anúncios publicitários parecem intensificar o potencial de atração dos produtos, ao associarem sua aquisição à imagem de ícones que se tornam amplamente conhecidos pelos telespectadores infantis, por meio das produçôes midiáticas presentes em seu cotidiano, tais como as que são protagonizadas pelas personagens Barbie, Hello Kitty e Max Steel. O processo de fidelização das crianças às marcas é reforçado pelo acréscimo de acessórios e brindes aos produtos, como as bolsas e brinquedos citados pelas meninas nas falas acima. Tendo em vista que assistir televisão se constituía como uma das principais atividades compartilhadas pelas crianças integrantes da pesquisa e que o conteúdo de programas como "TV Globinho" e "Malhação" permeava suas conversas e brincadeiras em sala de aula, pode-se supor que elas estivessem expostas a um volume considerável de convocaçôes ao consumo, sob a forma de marketing e propaganda, em sua vida diária.

Ao ressaltar correlações entre as narrativas das crianças sobre consumo e os anúncios comerciais, não pretendemos caracterizar a publicidade como uma instância que atua de forma determinante sobre as escolhas e preferências de consumo das crianças. Entretanto, ao atentar para as formas como as mercadorias são percebidas nas experiências relatadas no decorrer da pesquisa, não há como desconsiderar os efeitos das construçóes simbólicas da publicidade, pois é por meio destas que os bens de consumo adquirem condiçóes de verificaçáo no circuito social (ROCHA, 2006). Não por acaso, as crianças mencionam os comerciais televisivos, ao relatarem vontades e escolhas relacionadas à aquisiçấo de mercadorias, pois os anúncios publicitários associam o consumo a emoçóes, sensaçóes, visóes de mundo e estilos de vida, dotando as mercadorias de sentidos extra-mercantis. E ainda que o ato da compra não se efetive para um imenso contingente da populaçáo infantil, sobretudo em países como o Brasil, marcado por profundas desigualdades socioeconômicas, a torrente de imagens midiáticas faz do consumo uma aspiração viável para todas as crianças, ao menos no nível do imaginário e do intercâmbio de significados, capaz de engendrar o querer e o desejo.

\section{Considerações finais}

Neste artigo, buscou-se analisar as narrativas de um grupo de crianças sobre consumo, problematizando seus ditos em articulação com o advento do consumismo. Inicialmente, constatou-se que as crianças falavam sobre 
consumo a partir de registros narrativos legitimados pelos saberes escolares, focalizando aspectos inerentes à manutenção da vida e relacionados à preservação ambiental. Esses sentidos a respeito do consumo, circunscritos às açôes de usar, ingerir e exaurir, expressam necessidades invariáveis e universais, que se interpóem ao fenômeno do consumismo contemporâneo, o qual configura-se como um produto social e não um veredito inegociável da evolução biológica (BAUMAN, 2011).

Todavia, no momento em que as crianças foram instadas a relatar práticas de consumo que não se restringiam à satisfação de necessidades vitais, denotouse um importante deslocamento, o qual assume relação com o processo de renegociaçáo de sentidos promovido na trajetória da pesquisa. Sendo assim, quando impelidas a falar sobre as formas de consumo material e simbólico que forjam as experiências de infância, as crianças expressaram reiteradamente as disposiçóes de querer, desejar e comprar; condutas essas que se articulam ao modo de vida experimentado pelos membros da sociedade de consumidores. Cabe ressaltar que os membros dessa sociedade se relacionam com o mundo de uma forma primordialmente estética, percebendo-o como um alimento para a sensibilidade ou uma matriz de possíveis experiências, proporcionadas por desejos fugazes e satisfações momentâneas acionadas pelo consumo (BAUMAN, 1999b).

Desse modo, as análises apresentadas neste artigo colocam em destaque algumas alterações nas experiências de infância, que se engendram em correlação com as formas contemporâneas de consumo. Em primeiro lugar, as análises evidenciam modificações nas opções de lazer compartilhadas pelas crianças, que se deslocam dos espaços públicos de convívio infantil, para os espaços comerciais e também para os espaços privados. Essas mudanças assumem relaçóes com a frequência regular das crianças a espaços de consumo e ainda com o incremento e a popularização das possibilidades de compra, as quais permitem a aquisição e o uso individualizado de diversos bens, incluindo as tecnologias de informação e comunicação constantemente citadas pelas crianças nos encontros da pesquisa.

Em segundo lugar, os sentidos atribuídos pelas crianças aos bens de consumo que circulam nas interaçóes estabelecidas na escola indicam que algumas mercadorias operam como marcas de distinção e pertencimento. Sendo assim, é, sobretudo, por intermédio da posse e exibição de tais mercadorias, que as crianças são reconhecidas e inseridas nas relaçôes sociais no contexto escolar. Dentre essas marcas de pertencimento, figuram telefones celulares, 
câmaras fotográficas digitais, além de estilos de roupas e uma considerável variedade de objetos lúdicos e acessórios, tais como os óculos, relógios e pulseiras coloridas vinculadas às produçôes midiáticas. Ao focalizar esse aspecto, não pretendeu-se demarcar uma ruptura com as formas precedentes de consumo infantil, sugerindo que, em outras épocas, as crianças mantiveram relaçôes exclusivamente utilitárias com os bens materiais que circundavam suas vivências. Tampouco se trata de identificar um único propósito relacionado ao consumo, pois as análises apresentadas denotam que as experiências relatadas pelas crianças se inserem numa densa trama narrativa, entretecida no contexto de diversas instâncias socioculturais, tais como a escola, a família, os grupos de pares, a mídia etc.

Todavia, a estreita relação identificada entre os desejos de consumo expressos pelas crianças e o repertório midiático parece conferir às práticas de consumo infantis um importante redirecionamento: a redução do tempo de uso e fruição das mercadorias, por meio de atos consumistas de substituição e descarte. Assim, o caráter volátil e efêmero das atuais formas de consumo infantil institui-se em conexão com a profusão de mídias eletrônicas e com a renovação constante das demandas de consumo, por meio de mensagens comerciais que visam atingir as próprias crianças, posicionando-as não mais como consumidores em potencial, mas como consumidores efetivos.

Em síntese, pode-se afirmar que o advento do consumismo e outros fenômenos a ele correlatos, como a globalização econômica e cultural e a centralidade ocupada pelas mídias eletrônicas nos processos de produção e circulação de significados, articulam-se à reinvenção dos sentidos convencionais de infância. Nas sociedades contemporâneas, reguladas pelo consumo, as experiências das crianças são forjadas por instâncias e práticas culturais que não se restringem aos espaços-tempo da família e da escola, as duas instituições que se tornaram centrais na definição dos sentidos de infância que se consolidaram no decurso da Modernidade. Desse modo, a infância como um tempo de espera, ou um período de preparação para a vida adulta, dá lugar a uma "infância consumista", conduzida pelo imperativo da satisfação instantânea, imediata. Talvez, por esse motivo, as crianças de nosso tempo distanciem-se das ideias de resguardo, inaptidão e inocência que ainda nutrem o imaginário de muitos adultos, seus familiares e professores. Essas ideias parecem cada vez mais incompatíveis com os modos de ser e viver das crianças nascidas e educadas na sociedade de consumidores. 
Por fim, cabe destacar que as análises desenvolvidas neste estudo também instigam problematizaçóes acerca das abordagens de consumo vigentes nas propostas de Educação Ambiental que integram os currículos escolares. Nessa direçáo, consideramos pertinente ressaltar que as narrativas das crianças que explicitam vínculos com os saberes escolares não mencionam os aspectos sociais e simbólicos implicados nas práticas de consumo infantis. Assim, a criação de propostas educativas que potencializem a reflexão acerca do consumismo, enquanto fenômeno sociocultural que náo se restringe à questóes de ordem ecológica ou à condutas e escolhas privadas, apresenta-se como um desafio urgente e oportuno para as práticas de Educação Ambiental voltadas para as crianças na atualidade.

\section{Notas}

${ }^{1} \mathrm{Na}$ obra intitulada Modernidade e ambivalência, Bauman (1999a) esclarece que compreende a Modernidade como um período histórico que teve início na Europa Ocidental, no século XVII, com profundas transformaçóes socioestruturais e intelectuais, atingindo sua maturidade primeiramente como projeto cultural, com o avanço do Iluminismo, e depois como forma de vida consumada, com o desenvolvimento da sociedade industrial.

${ }^{2}$ Neste estudo, compreendemos a Educação Ambiental como "uma construçấo cultural, na medida em que os significados e os discursos que a constroem não existiram desde sempre, mas emergiram a partir de uma determinada conjuntura histórica" (SAMPAIO, 2009, p. 135-136). A partir desse caráter de construção cultural, consideramos a Educação Ambiental não como um território homogêneo, mas como um campo matizado e contestado, em que múltiplas teorizaçóes, práticas e formas de abordagem são configuradas, em meio às tensôes, disputas e negociações que definem os significados sobre o ambiental.

${ }^{3}$ Ao todo, noventa e cinco crianças participaram dos encontros da pesquisa. A participação delas foi autorizada e formalizada mediante a entrega de um folheto explicativo, acompanhado do Termo de Consentimento Livre e Esclarecido, que informava a direção da escola, professoras e familiares das crianças sobre os procedimentos da pesquisa. 
${ }^{4} \mathrm{O}$ vídeo em questão foi produzido para os fins da pesquisa, com a intençấo de comunicar às crianças os objetivos e a temática do estudo. Além disso, permitiu colocar as crianças a par das atividades que seriam desenvolvidas no decorrer da investigação. Com isso, as crianças puderam optar por participar ou não da pesquisa, dispondo de informações e esclarecimentos sobre o seu desenvolvimento no espaço da escolar.

${ }^{5}$ Um camelódromo é um espaço comercial onde se concentram vendedores que, em geral, ofertam produtos importados, obtidos legalmente ou não. No município de Rio Grande, RS, o camelódromo, ou Centro de Comércio Informal, foi construído pela Prefeitura Municipal, promovendo a transferência de vendedores ambulantes que se localizavam nas imediaçóes da principal praça da cidade para um amplo local, com bancas padronizadas.

${ }^{6}$ As "mercadorias simulacro", citadas por Costa (2006), consistem em réplicas ou imitaçóes de produtos associados a uma marca que lhes conferem identidade. As mercadorias simulacro apresentam aparência similar aos produtos licenciados, embora se diferenciem destes em razáo de sua procedência e qualidade, o que também permite sua aquisição em redes de comércio informal. A boneca Barbie é um exemplo ilustrativo desse processo, pois, além do artefato lúdico original, produzido e distribuído pela companhia de brinquedos Mattel, diversas versóes da boneca podem ser encontradas em feiras e bancas de camelôs, por menos da metade do preço cobrado nas lojas pela boneca da marca licenciada. Isso permite que as crianças das camadas populares compartilhem as experiências de consumo que produzem as infâncias economicamente privilegiadas, o que não significa que as distinçóes entre as mercadorias simulacro e as mercadorias originais náo sejam percebidas pelas crianças ou que não promovam hierarquias e exclusôes nos círculos sociais.

${ }^{7}$ Trata-se do livro infantil intitulado Eu preciso tanto, de autoria de Shirley Souza (2009).

${ }^{8}$ Refiro-me aos telefones celulares chamados "smartphones", os quais integram diversas funcionalidades, tais como a possibilidade de conexão à internet e a capacidade de sincronização de dados com computadores pessoais. 
${ }^{9}$ Restart é nome de uma grupo musical formado por quatro adolescentes brasileiros. Em 2009, a banda Restart tornou-se popularmente conhecida, adquirindo notoriedade pelo uso de roupas e acessórios coloridos.

${ }^{10}$ Orkut é a designação de uma rede social que permite a criação de perfis e comunidades por afinidades de interesses. O site também disponibiliza ferramentas de bate-papo e visualização de fotos e mensagens postadas por seus usuários. Atualmente, o Orkut perdeu espaço para outros sites de redes sociais como Twitter e Facebook. Entretanto, no ano de 2010, quando foram realizados os encontros da pesquisa com as crianças, o Orkut era o principal site de relacionamento utilizado pelos internautas brasileiros.

\section{REFERÊNCIAS}

BAUMAN, Zygmunt. Modernidade e ambivalência. Rio de Janeiro: Jorge Zahar, 1999a.

BAUMAN, Zygmunt. Globalização: as consequências humanas. Rio de Janeiro: Jorge Zahar, $1999 \mathrm{~b}$.

BAUMAN, Zygmunt. Modernidade Líquida. Rio de Janeiro: Jorge Zahar, 2001.

BAUMAN, Zygmunt. Trabajo, consumismo y nuevos pobres. Barcelona: Gedisa, 2005.

BAUMAN, Zygmunt. Vida líquida. Rio de Janeiro: Jorge Zahar, 2007.

BAUMAN, Zygmunt. Vida para consumo: a transformação das pessoas em mercadoria. Rio de Janeiro: Jorge Zahar, 2008.

BAUMAN, Zygmunt. 44 cartas do mundo líquido moderno. Rio de Janeiro: Jorge Zahar, 2011.

BARBOSA, Lívia; CAMPBELL, Colin. O estudo do consumo nas ciências sociais contemporâneas. In: BARBOSA, Lívia; CAMPBELL, Colin (Org.). Cultura, consumo e identidade. Rio de Janeiro: Editora FGV, 2006. p. 21-44.

BUCKINGHAM, David. Crescer na era das mídias eletrônicas. São Paulo: Loyola, 2007. 
BUJES, Maria Isabel Edelweiss. O fio e a trama: as crianças nas malhas do poder. Educação \& Realidade, Porto Alegre, v. 25, n. 1, p. 25-44, jan./jul. 2000 .

BUJES, Maria Isabel Edelweiss. Infância e maquinarias. Rio de Janeiro: DP\&A, 2002.

CANCLINI, Néstor García. Consumidores e cidadãos: conflitos multiculturais da globalização. Rio de Janeiro: Editora da UFRJ, 2005.

CASTRO, Lucia Rabello de. Da invisibilidade à ação: crianças e jovens na construção da cultura. In: CASTRO, Lucia Rabello de (Org.). Crianças e jovens na construção da cultura. Rio de Janeiro: NAU, 2001. p. 19-14.

CONNELLY, Michael; CLANDININ, Jean. Relatos de experiencia e investigación narrativa. In: LARROSA, Jorge et al. Déjame que te cuente. Barcelona: Laertes, 1995. p. 11-59

COSTA, Marisa Vorraber. Paisagens escolares no mundo contemporâneo. In: SOMMER, Luís Henrique; BUJES, Maria Isabel Edelweiss (Org.). Educação e cultura contemporânea: articulaçôes, provocaçôes e transgressões em novas paisagens. Canoas, RS: Editora da ULBRA, 2006. p. 151-195.

COSTA, Marisa Vorraber. Sobre as contribuiçôes das análises culturais para a formação de professores do início do século XXI. Educar, Curitiba, n. 37, p. 129-152, maio/ago. 2010.

DELGADO, Ana Cristina Coll; MÜLLER, Fernanda. Abordagens etnográficas nas pesquisas com crianças. In: CRUZ, Silvia Helena Vieira (Org.). A criança fala: a escuta de criança em pesquisas. São Paulo: Cortez, 2008. p. 141-157.

DORNELLES, Leni Vieira. Infâncias que nos escapam: da criança de rua à criança cyber. Petrópolis, RJ: Vozes, 2005.

DOUGLAS, Mary; ISHERWOOD, Baron. $O$ mundo dos bens: para uma antropologia do consumo. Rio de Janeiro: Editora da UFRJ, 2009.

LARROSA, Jorge. LARROSA, Jorge. La experiencia de la lectura. Barcelona: Laertes, 1996. 
LARROSA, Jorge. Tecnologias do eu e educação. In: SILVA, Tomaz Tadeu (Org.). O sujeito da educação: estudos foucaultianos. Petrópolis, RJ: Vozes, 2008. p. 35-83.

LINN, Susan. Crianças do consumo: a infância roubada. São Paulo: Instituto Alana, 2006.

LIPOVETSKY, Gilles. A felicidade paradoxal: ensaio sobre a sociedade de hiperconsumo. São Paulo: Companhia das Letras, 2007.

MCCRACKEN, Grant. Cultura e consumo: novas abordagens ao caráter simbólico dos bens e das atividades de consumo. Rio de Janeiro: MAUAD, 2003.

MOREIRA, Antonio; SILVA, Tomaz Tadeu da. Sociologia e teoria crítica do currículo: uma introdução. In: MOREIRA, Antonio; SILVA, Tomaz Tadeu da (Org.). Currículo, cultura e sociedade. São Paulo: Cortez, 2008. p. 7-37

NARODOWSKI, Mariano. Después de clase: desencantos y desafios de la escuela actual. Buenos Aires: Novedades Educativas, 1999.

PORTILHO, Fátima. Consumo verde, consumo sustentável e a ambientalização dos consumidores. In: ENCONTRO DA ANPPAS, 2., 2004, Indaiatuba. Anais... Indaiatuba, SP: ANPPAS, 2004. Disponível em: <http:// xa.yimg.com/kq/groups/21118932/984448213/name/Consumo+Verde+C onsumo+Sustentavel+e+a+Ambientalização+dos+Consumidores_PORTILHO.pdf>. Acesso em: 10 dez. 2012.

REIGOTA, Marcos. A floresta e a escola: por uma educação ambiental pós-moderna. São Paulo: Cortez, 2002.

ROCHA, Everardo. Representaçóes do consumo: estudos sobre a narrativa publicitária. Rio de Janeiro: Editora da PUC-Rio; MAUAD, 2006.

ROCHA, Everardo. Os bens como cultura: Mary Douglas e a antropologia do consumo. In: DOUGLAS, Mary; ISHERWOOD, Baron. O mundo dos bens: para uma antropologia do consumo. Rio de Janeiro: Editora da UFRJ, 2009. p. 7-18

SAMPAIO, Shaula Maíra Vicentini. Notas sobre a fabricação de educadores/as ambientais: identidades sob rasuras e costuras. Dissertação (Mestrado em Educação) - Universidade Federal do Rio Grande do Sul, Porto Alegre, 2005. 
SAMPAIO, Shaula Maíra Vicentini. A construção de uma pesquisa e suas reviravoltas: relato sobre uma investigação que articula Educação Ambiental e Estudos Culturais. In: FERREIRA, Taís; SAMPAIO, Shaula Maíra Vicentini. Escritos metodológicos: possibilidades na pesquisa contemporânea em educação. Maceió: EDUFAL, 2009. p. 131-147.

SCHOR, Juliet. Nascidos para comprar: uma leitura essencial para orientarmos nossas crianças na era do consumismo. São Paulo: Gente, 2009.

SOUZA, Shirley. Eu preciso tanto. São Paulo: Escala Educacional, 2009.

WORTMANN, Maria Lúcia Castagna; RIPOLL, Daniela; POSSAMAI, Laís. Educação ambiental corporativa para crianças: analisando a animação Peixonauta do Discovery Kids. Perspectiva, Florianópolis, SC, v. 30, n. 2, p. 371-394, maio/ago. 2012. 
Comprar, querer y desear: problematizando las narrativas de niños de la educación primaria acerca del consumo

\section{Resumen}

Este artículo analiza las concepciones y experiencias de la infancia como construcciones históricas, sociales y culturales, sujetas a los cambios que caracterizan a las sociedades. En esta investigación, se establecen conexiones entre los estudios sobre la infancia, la educación ambiental y las proposiciones del sociólogo Zygmunt Bauman en su análisis sobre la importancia asumida por el consumismo en la organización de la vida social. Por lo tanto, la mirada se concentra en el consumismo y las configuraciones de la infancia en la sociedad contemporánea analizando los relatos de un grupo de niños de escuela primaria acerca del consumo. En las experiencias narradas, se destaca la relación entre el consumo y la conservación del medio ambiente, la omnipresencia del acto de compra en la vida cotidiana infantil, así como la atribución de sentidos a los objetos y prácticas de consumo más allá de la funcionalidad del material.

Palabras claves: Infancia. Consumismo. Educación Ambiental.

\section{Buy, want and desire: discussing elementary school children's narratives on consumption}

\section{Abstract}

This article discusses the understandings and experiences of childhood as historical, social and cultural constructions, subject to the changes characterizing societies. Connections are established between Childhood Studies, Environmental Education and the propositions of the sociologist Zygmunt Bauman in his examination of the centrality assumed by consumerism in the organization of social life. Therefore, the gaze is turned to the advent of consumerism and childhood settings in contemporary society by analyzing the narratives of a group of elementary school children on consumption. In the narrated experiences, noteworthy are the relationship between consumption and environmental preservation, the pervasiveness of the purchase act in children's daily life as well as the attribution of meanings to objects and consumption practices beyond the material functionality. Keywords: Childhood. Consumerism. Environmental Education. 
Joice Araújo Esperança

E-mail: joiceesp@yahoo.com.br

\section{Paula Costa Ribeiro}

E-mail: pribeiro@vetorial.net

Enviado em: 1/7/2013

Versáo final: 23/2/2014

Aprovado em: 28/2/2014 